UDC 316.77(4/9)

\title{
Functional traits of the media space in Kazakhstan in the context of globalization
}

\author{
Zenebe Tafesse Kinfu, Alina A. Fadeeva \\ Peoples' Friendship University of Russia (RUDN University) \\ 10 Miklukho-Maklaya St, bldg. 2, Moscow, 117198, Russian Federation
}

This article is devoted to the study of the functional features of the media space in Kazakhstan under the rapidly changing globalization trends and information confrontation of world powers. Since gaining independence, Kazakhstan is striving to create its own independent information space. The process of information space formation in the country has several traits, such as low competitiveness of national news agencies, slow development of the regulatory and legal framework in the field of information security, high politicization, including the language issue. These features occurred due to the heterogeneous language environment, the problems of the formation of national independent news agencies, the challenges of globalization, the most pressing of which is the growing influence of global media. In this article, authors touch upon the transition of Kazakhstan to the Latin alphabet, as well as the views of Western, Russian and Kazakhstan researchers on the current state of the media landscape of Kazakhstan. Authors justify the need to work out ways to minimize external information impact on the media landscape of Kazakhstan that is still undergoing media transformation processes.

Keywords: media space, information area, information security, globalization, external influence, Kazakhstan, West, Russia, Eurasian integration

\section{Introduction}

The speed and direction of social and political changes and ongoing ways of social development will be highly determined by the formation of media sphere and information technology. According to the new political paradigm, Kazakhstan is considered as a driver for Eurasian integration in the post-Soviet area thereby having a significant impact on the formation of the Eurasian media sphere. In Kazakhstan and other post-soviet countries, politicized media are the most popular as they influence the ongoing domestic policy and political transformation in the independent republics. The issues of the modern information society make modern media an object of influence from various global forces.

In modern conditions of information confrontation between Russia and the West, it is necessary to monitor the degree of global media influence on the information space of individual countries. In the context of abovementioned rapidly growing tensions, the authors of this article aim to analyze the current state of the media

(C) Kinfu Z.T., Fadeeva A.A., 2020

(c) (i) This work is licensed under a Creative Commons Attribution 4.0 International License https://creativecommons.org/licenses/by/4.0/ 
sphere in Kazakhstan, its transformation peculiarities in the context of rapidly changing globalization trends, information confrontation of world powers, and the growing politicization of society as a whole.

\section{Thesaurus "information space" and "media space"}

There are various definitions, concerning the terms "media space" and "information space". R. Stults and S. Harrison (1980) define media space as a space created by electronic means of communication, in which individuals or their groups and other communities can act together at the same time and influence each other [1]. In his works the Canadian philosopher, philologist and literary critic Marshall McLuhan referred to media space as the electronic information space [2].

Evgeniy Prokhorov's definition of a single information space deserves attention: “...an integral information space means the presence of an information field of high density that enables everyone to receive all the necessary and sufficient information according to the realities of life - region, country, world and to develop opinions, attitudes, and make decisions" [3].

Therefore, the development of media sphere is directly related to the density of information space and political space. The greater the amount of information circulating in society, the more actively the media system works, providing complete coverage of events occurring in society.

The term "media", like "data", is the plural form of a word borrowed from Latin, and this term is now common in the fields of mass communication and advertising. The definitions of "media" adopted in different countries carry the same meaning [4]. Probably for this reason, the terms "information space", "media space" and "media sphere" are often used as synonyms in Russia.

It should be noted that the degree of development of the media system in any state today directly depends on the degree of integration of its media into the global media sphere. Media globalization includes many aspects, given that the media themselves form the global information field, at the same time they are the main channel through which information flows, forming the interconnectedness system of the whole world [3].

Nowadays, the state of the media is largely determined by the quantity and quality of Internet publications and the development of Internet technologies. Several researchers believe that the media space contains all sorts of psychological and political threats, for example, D. Rushkoff argues that the components of the modern media contain information viruses that affect people's worldview. In the huge flow of information, modern media "catch" their readers with the help of controversial, compelling images or ideas, the so-called media viruses, that allow countercultural politics to infiltrate mainstream media [16]. Politically oriented media mostly use these inserts to increase their ratings as this information attracts a sizable audience.

Modern media influence the establishment of the agenda in any state, transforming the mechanisms of its interaction with society, changing the basic technologies and methods of mass communication. Thus, the study of the Kazakhstan information space development is relevant for the analysis of the attitudes and political views, expressed by the citizens of Kazakhstan. 


\section{Formation of the Kazakhstan's national media space and information security}

Current media system of the Republic of Kazakhstan is at the stage of its formation. The modern information space is variable and the patterns of interaction with information security risks are not yet fully developed.

In the summer of 2003, the Institute of Philosophy and Political Science of the Ministry of Education and Science of Kazakhstan, KazNU Al-Farabi and the Center for Humanitarian Studies in Almaty presented the peer review of the Kazakhstan's media space. According to this review, Russian media space remains the most advanced among the CIS countries and has a strong influence on the information space of other post-Soviet Central Asian countries [5]. The official languages of Kazakhstan are Kazakh with 5,290,000 speakers around the country and Russian, which is spoken by 6,230,000 people. Despite the intention of state-owned media to withdraw from Russian sources of information to preserve their own national viewpoints, a high prevalence and popularity of Russian-language content, partly derived from Russian media characterizes the media space in Kazakhstan as a whole. According to official statistics, in 2009, 84.8\% of Kazakhstanis showed a high degree of proficiency in writing and reading skills in Russian language (Kazakh language - 62\%, in English - 7.7\%), 94.4\% understood oral Russian (74\% in Kazakh, English - 15.4\%) [6]. According to the country's Ministry of Culture and Sports, in 2016 the share of Russian-speaking citizens was 89.4\% [7]. Since 2011, Kazakhstan has a state program for the development and functioning of languages within the framework of the Kazakhstan-2050 strategy. According to this program, the proportion of the Russian-speaking population is planned to be increased to $90 \%$ by 2020 [17]. In addition, by 2020 it is planned to increase the number of people who speak three languages (official Kazakh language, Russian, and English) by $15 \%$ [17].

Currently, there are 2,972 mass media units in Kazakhstan. Statistics indicate that in 2016 the number of operating media increased by $10 \%$ compared with the previous year [8]. According to the 2016 census, ethnic Kazakhs make up about two-thirds of the population, while ethnic Russians are about 20\%. However, statistics shows that nearly everyone in country speaks Russian - roughly $94 \%$ of the more than 18 million citizens are fluent in it. Kazakh language fluency is at second place, at $74 \%$. The language of Kazakhstan's media varies by region. For example, in the Karaganda region, there are $36 \%$ of Russian-language media organizations, $61 \%$ of the media operates two or more languages, and only $3 \%$ of the media operates national language (Kazakh). In Zhambyl oblast there are $21 \%$ of Russian-language mass media and $23 \%$ of Kazakh-language mass media and $56 \%$ of mass media publish materials in two or more languages. In Almaty there are $19 \%$ of the Kazakhlanguage media, $46 \%$ of the Russian-language media, $35 \%$ of media are published in two or more languages [8]. According to statistics, more than $70 \%$ of the media in Kazakhstan are officially independent, but over the past few years, the number of state-owned media steadily increases. For instance, in 2014, the share of state-owned media made up only $16 \%$, but in 2016 , it increased to $25 \%$ of the total [9. P. 14].

Dosym Satpayev, a prominent political analyst in Kazakhstan claimed in an interview that the Russian media in the Internet have a significant influence on the pub- 
lic opinion in Kazakhstan. According to D. Satpayev "in the near future, Kazakhstan will be a bone of contention in terms of informational clashes between various large geopolitical players, who already use information weapons as an important element of their geopolitical game" [10].

Thus, many experts believe, that Kazakhstan is weakly integrated into the global media space; however, the state officials stand for creation of the Eurasian media space in the region [10]. Despite the need for information interaction with the outside world, many researchers express their concerns about external influence, which causes such problems as a relatively high rating of foreign media in Kazakhstan, Russian influence over Kazakhstan's media and information space, the impact of Western values distributed through entertainment programs on the country's young generation [11]. According to statistics, young people between the ages of 20 and 44 are active Internet users and they express interest in globalization trends. Programs broadcasted through the BBC, Radio Liberty, the Current Time TV \& digital network, and the Russian media are quite popular among Kazakhstanis. In Kazakhstan, more than 80 foreign media representatives from two dozen countries of the world are accredited, including the largest information agencies - BBC, Associated Press, Interfax, France-Presse, Xinhua, Reuters, ITAR-TASS, etc. [8].

Among all media sectors, the Internet and computer technologies show the highest rates of development in Kazakhstan. The country is gradually becoming a full-fledged member of the international media market and the Kazakhstani media shows relative impact on neighboring countries [5]. The Internet in Kazakhstan first appeared in 1991 and in 2001 the Internet websites received the status of the media [11. Pp. 55-60]. On September 19, 1994, the domain .kz was registered in the database of the Internet Corporation for Assigned Names and Numbers (ICANN).

Despite the obvious effects of globalization represented by steady influence of foreign media on Kazakhstani society, national and regional press and electronic media ratings keep growing. They remain in demand as they highlight the situation in the regions. $35 \%$ of newspapers are circulated in major cities - Astana and Almaty, in the regions there are $65 \%$ of them, and it indicates the demand for newspapers in the regions. According to the Statistics Committee of the Ministry of National Economy of the Republic of Kazakhstan, about 30\% of electronic media are accumulated in Almaty and Astana and 70\% of them are distributed in the remaining regions [9]. According to Kazakhstani analysts, usage of Kazakh language makes regional media less vulnerable to external information influence. Many Kazakhstani media experts have repeatedly expressed the need for information sovereignty and the transfer of foreign electronic media to cable networks. The owner of the TAN media group, Armanzhan Baytasov, and a PR technology specialist, Yerlan Askarbekov, openly called for limiting the retransmission of Russian TV channels that "disseminate political information" [12]. However, such a measure can only be effective in relation to television, while the main information threats today are spread through the Internet, which has no limits.

Eric Freedman, Associate Professor of Journalism, Assistant Dean of International Studies \& Programs, Michigan State University, and Richard Schafer, Ph.D. Professor of Journalism, Department of English, University of North Dakota [13], in their studies of Central Asian media consider the information struggle 
of superpowers eager to impact the media space of post-Soviet countries. During the opening of the third session of the Parliament President Nursultan Nazarbayev also mentioned threats to the information space security, saying, "We need a reliable 'Cyber shield of Kazakhstan'. We cannot postpone its creation. It is necessary to protect the interests of our country, our culture, our values. It is a matter of safety" [14]. In 2009, Karim Masimov, the Prime Minister of the Republic of Kazakhstan openly stated that $55 \%$ of the citizens of Kazakhstan live in the Russian information space [11. P. 49].

According to Eric Freedman and Richard Shafer, the press in five Central Asian countries is still in the shadow of the post-Soviet past. However, after the collapse of the Soviet Union, western democracies offered the democratic system of media development, which was actively introduced through the preparation of a new generation of journalists. Barbara Junisbai, Assistant Professor of Organizational Studies at Pitzer College in her research emphasizes the negative role of "financial-industrial" groups, related to the country officials that use the media as a "strong weapon" in the internal struggle for wealth and power. In her work, Barbara Yunisbai describes how an authoritarian government uses formally "independent" media to retain power, without officially violating democratic standards [13]. Thus, many foreign researchers consider the functioning of the information space of Kazakhstan exclusively through the prism of the political situation in the country.

In 2018, significant language changes started in Kazakhstan after President Nursultan Nazarbayev signed a decree on amending the Decree of the President of the Republic of Kazakhstan dated October 26, 2017 No. 569 "On translation of the Kazakh alphabet from Cyrillic to the Latin alphabet". The President of the Kazakhstan ordered to develop a schedule and begin the necessary preparatory work, planning to complete the transition by 2025 [17]. This decree aroused the indignation of the Russian-speaking audience and the cautious attitude of Russian experts, some of them regarded the transition as ideologically motivated act [15]. This led to anti-Russian rhetoric among Kazakh-speaking Internet users and experts. "The transition of the Kazakh script to the Latin alphabet is an important step towards decolonization; it means release of the imposed alphabet, gaining freedom. We can see that some political circles in Russia have expressed concern that we are moving away from the Russian cultural space. However, it cannot be denied that many peoples who use Latin script have close ties with Russian culture. Therefore, the Kazakh-Russian economic, cultural and scientific ties will develop further," said the Kazakh scholar Amangeldy Aitaly on the Kazakh-language portal kerey.kz [15]. The transition to the Latin-based style in the Kazakhstani media is often associated with the language and inter-ethnic issues, directly affecting the information space of Kazakhstan as a whole. Western media, like BBC, described this transition as a positive step towards globalization.

\section{Conclusion}

In conclusion, the media space of Kazakhstan is at the active stage of forming its own national information field. The information space of the country is formed by both external and internal factors, such as: the influence of the world media space, the lack of a clear social and political position, including the language is- 
sues as well; financial difficulties and the lack of properly educated professionals to create due amount of relevant content; global data verification problems. In order to reduce the influence of external sources, Kazakhstani media have to produce competitive content of high quality. The lack of financial and qualified human resources remains an obstacle for further development of media space. Therefore, there is a need to obtain information from the outside, which is then processed by the owners of the state media, interpreted and supplemented according to the desired effect. In addition, there is a need to study the development of Kazakhstani media space as a system with specific regional characteristics and the need to develop adequate responses to global challenges.

Moreover, the media forming the national media space should precisely reflect the social and political processes currently taking place in the country and in the world. Weak representativeness of the modern media space in Kazakhstan is obvious as it mainly reflects the position of the media owners or the position of a certain NGO or foreign information agency, that forms the information field in the country according to its own agenda. Kazakhstani media should develop risk management and find proper ways to minimize external information threats.

\section{References}

[1] Stults, R. (1986). Media Space, Xerox PARC. Retrieved from http://people.cs.vt.edu/ srh/Downloads/Media\%20Space\%20Report.pdf (accessed: 15.03.2019).

[2] McLuhan M. (1962). The Gutenberg Galaxy: The Making of Typographic Man. Toronto: University of Toronto Press.

[3] Prokhorov, E.P. (1999). Regional'naya pressa v informatsionnom prostranstve Rossii [Regional press in Russian media landscape]. Retrieved from http://www.dzyalosh.ru/ 01-comm/books/regional-press/prohorov.html (accessed: 16.03.2018). (In Russ.)

[4] Fedorov, A.V. (2014). Slovar' terminov po mediaobrazovaniyu, mediapedagogike, mediagramotnosti, mediakompetentnosti [Dictionary of media education, media pedagogy, media literacy, media competence terms]. Moscow: Direct-media Publ. (In Russ.)

[5] Ibraeva, G.Zh., Petrenko, S.Yu., \& Buluktaev, Yu.O. (2004). Ekspertnaya otsenka mediaprostranstva Kazakhstana [Expert evaluation of the media landscape in Kazakhstan]. Retrieved from http://ecsocman.hse.ru/data/832/922/1219/013.IBRAEVA.pdf (accessed: 15.03.2019). (In Russ.)

[6] Ministry of National Economy of the Republic of Kazakhstan. Committee on Statistics. (2018). Pokazateli gosudarstvennykh i pravitel'stvennykh program [Indicators of state and government programs]. Retrieved from http://stat.gov.kz/faces/homePage/home Programm.pokazateli?_adf.ctrl-state $=$ jr925mgus_86\&_afrLoop $=2339583839098541 \#$ \%40\%3F_afrLoop\%3D̄2339583839098541\%26_adf.ctrl-state\%3Db8ferpvz7_4 (accessed: 20.06.2019). (In Russ.)

[7] Slobodyan, E. (2018, 20 February). Skol'ko v Kazakhstane russkoyazychnogo naseleniya? [How many Russian-speaking population is in Kazakhstan?] Argumenty i Fakty [Arguments and Facts]. Retrieved from http://www.aif.ru/society/people/skolko_v_ kazahstane_russkoyazychnogo_naseleniya (accessed: 20.06.2019). (In Russ.)

[8] Interorga.ru. (2018). O razvitii SMI v Kazakhstane [The Development of Mass Media in Kazakhstan]. Retrieved from http://interorga.ru/mezhdunarodnye-otnosheniya/kazahstanv-mezhdunarodnyh-organizatsciyah/o-razvitii-smi-v-kazahstane.html (accessed: 20.06.2019). (In Russ.)

[9] BISAM Central Asia. Sociological and Marketing Research Center. (2016). Itogovyi otchet po rezul'tatam marketingovogo issledovaniya faktorov tarifoobrazovaniya uslug 
sredstv massovoi informatsii respubliki Kazakhstan s tsel'yu rascheta tarifnykh stavok dlya zakupki uslug po realizatsii gosudarstvennoi informatsionnoi politiki [Final report on the results of marketing research of rates setting factors for media services in the Republic of Kazakhstan with a view to calculating rates setting for the procurement of public information policy services]. Almaty. Retrieved from mic.gov.kz/sites/default/ files/pages/finalnyy_itogovyy_otchet_rus.pdf (accessed: 20.06.2019). (In Russ.)

[10] Drobyazko, E. (2015). V Kazakhstane nachalas' informatsionnaya voina - politolog [Information war started in Kazakhstan - politologist]. OpenAsia. Retrieved from $\mathrm{http}: / /$ theopenasia.net/ articles/detail/v-kazakhstane-nachalas-informatsionnaya-voynapolitolog/ (accessed: 15.03.2019). (In Russ.)

[11] Sabitov, D. (2016). Informatsionnaya bezopasnost' Kazakhstana: zashchita dannykh $i$ smyslov [Information security of Kazakhstan: protection of data and meanings]. Institute of World Economy and Politics (IWEP) under the Fund of the First President of the Republic of Kazakhstan - The Leader of the Nation. Astana, Almaty. Retrieved from http://iwep.kz/files/attachments/article/2016-04-07/doklad_informacionnaya_bezopasnost_ daniyar_sabitov.pdf (accessed: 15.03.2019). (In Russ.)

[12] Central Asia Monitor. (2014). Ugrozhayut li Kazakhstanu rossiiskie SMI? [Does Russian media threaten Kazakhstan?]. Retrieved from https://camonitor.kz/13908-ugrozhayutli-kazahstanu-rossiyskie-smi-aivanov.html (accessed: 15.03.2019). (In Russ.)

[13] Fridman, E., \& Sheifer, R. (2011). New developments in Central Asian mass media research. Central Asia and the Caucasus, 14(4), 143-162.

[14] Digital Report. (2017, 7 September). Prezident Kazakhstana rasstavil prioritety: tsifrovizatsiya i kiberbezopasnost' na 8 meste [The President of Kazakhstan prioritized: digitalization and cybersecurity in the $8^{\text {th }}$ place]. Retrieved from https://digital.report/ prezident-kazahstana-rasstavil-prioritetyi-tsifrovizatsiya-i-kiberbezopasnost-na-8-meste/ (accessed: 20.06.2018). (In Russ.)

[15] Bakhtigareev, R. (2017, 10 May). Bol'she ne mnogonatsional'nyi: Obzor SMI Kazakhstana [No longer multinational: Review of Kazakhstani media]. Regnum. Retrieved from https://regnum.ru/news/2273031.html (accessed: 15.03.2019). (In Russ.)

[16] Rushkoff, D. (1994). Media Virus! Hidden Agendas in Popular Culture. New York: Ballantine Books.

[17] Strategy "Kazakhstan-2050". (2018). Gosudarstvennaya programma razvitiya i funktsionirovaniya yazykov $v$ RK [State Program for the Development and Functioning of Languages in the Republic of Kazakhstan]. Retrieved from https://strategy2050.kz/ru/page/ gosprog5/ (accessed: 20.06.2019). (In Russ.)

\section{Article history:}

Received: 31 January 2019

Revised: 15 March 2019

Accepted: 10 October 2019

\section{For citation:}

Kinfu, Z.T., \& Fadeeva, A.A. (2020). Functional traits of the media space in Kazakhstan in the context of globalization. RUDN Journal of Studies in Literature and Journalism, 25(1), 168-176. http://dx.doi.org/10.22363/2312-9220-2020-25-1-168-176

\section{Bio notes:}

Zenebe Tafesse Kinfu, PhD, Associate Professor of the Department of Mass Communication, Faculty of Philology, Peoples' Friendship University of Russia (RUDN University). E-mail: zen888kin@yandex.ru

Alina A. Fadeeva, PhD student, Department of Mass Communication, Faculty of Philology, Peoples' Friendship University of Russia (RUDN University). E-mail: alina.fadeeva1092@, gmail.com 


\title{
Особенности функционирования медиапространства Казахстана в условиях глобализации
}

\author{
3.Т. Кинфу, А.А. Фадеева \\ Российский университет дружбы народов \\ Российская Федераџия, 117198, Москва, ул. Миклухо-Маклая, д. 10, корп. 2
}

Статья посвящена исследованию медиапространства Республики Казахстан в условиях стремительно меняющихся глобализационных трендов и информационного противостояния мировых держав. С момента получения независимости Казахстан стремится к созданию собственного независимого информационного пространства. Этот процесс имеет ряд особенностей, таких как низкая конкурентоспособность национальных информационных агентств, медленное развитие нормативно-правовой базы в сфере обеспечения информационной безопасности, высокая политизированность, в том числе и в языковом вопросе, что обусловлено неоднородной языковой обстановкой, проблемами формирования национальных независимых информационных агентств, вызовами глобализации, самым актуальным из которых является растущее влияние глобальных СМИ. В статье затрагивается вопрос перехода Казахстана на латиницу, а также взгляды западных, российских и казахстанских исследователей на современное состояние медиапространства Казахстана. Обосновывается необходимость выработки путей минимизации внешнего информационного влияния на медиапространство Казахстана, которое все еще находится на этапе цифровой трансформации.

Ключевые слова: медиапространство, информационное поле, информационная безопасность, глобализация, внешнее влияние, Казахстан, Запад, Россия, евразийская интеграция

\section{Список литературы}

[1] Stults R. Media Space, Xerox PARC. 1986. URL: http://people.cs.vt.edu/srh/ Downloads/Media\%20Space\%20Report.pdf (дата обращения: 15.03.2019).

[2] Маклюэн М.Г. Галактика Гутенберга. Сотворение человека печатной культуры. Киев: Ника-Центр, 2004. 432 с.

[3] Прохоров Е.П. Региональная пресса в информационном пространстве России. URL: http://www.dzyalosh.ru/01-comm/books/regional-press/prohorov.html (дата обращения: 16.03.2019).

[4] Федоров А.В. Словарь терминов по медиаобразованию, медиапедагогике, медиаграмотности, медиакомпетентности. М.: Директ-медиа, 2014. 62 с.

[5] Ибраева Г.Ж., Петренко С.Ю., Булуктаев Ю.О. Экспертная оценка медиапространства Казахстана. URL: http://ecsocman.hse.ru/data/832/922/1219/013.IBRAEVA.pdf (дата обращения: 15.03.2019).

[6] Показатели государственных и правительственных программ / Министерство национальной экономики Республики Казахстан. Комитет по статистике. 2018. URL: http://stat.gov.kz/faces/homePage/homeProgramm.pokazateli?_adf.ctrlstate=jr925 mgus_86\&_afrLoop=2339583839098541\#\%40\%3F_afrLoop\%3D2339583839098541 \%26_adf.ctrl-state\%3Db8ferpvz7_4 (дата обращения: 20.06.2019).

[7] Слободян E. Сколько в Казахстане русскоязычного населения? // Аргументы и факты. 2018, 20 февраля. URL: http://www.aif.ru/society/people/skolko_v_kazahstane_ russkoyazychnogo_naseleniya (дата обращения: 20.06.2019). 
[8] О развитии СМИ в Казахстане // Interorga.ru. 2018. URL: http://interorga.ru/ mezhdunarodnye-otnosheniya/kazahstan-v-mezhdunarodnyh-organizatsciyah/o-razvitiismi-v-kazahstane.html (дата обращения: 20.06.2019).

[9] Итоговый отчет по результатам маркетингового исследования факторов тарифообразования услуг средств массовой информации Республики Казахстан с целью расчета тарифных ставок для закупки услуг по реализации государственной информационной политики / Центр бизнес-информации, социологических и маркетинговых исследований BISAM Central Asia. Алматы, 2016. URL: mic.gov.kz/sites/ default/files/pages/ finalnyy_itogovyy_otchet_rus.pdf (дата обращения: 20.06.2019).

[10] Дробязко E. В Казахстане началась информационная война // OpenAsia. 2015. URL: http://theopenasia.net/articles/detail/v-kazakhstane-nachalas-informatsionnaya-voynapolitolog/ (дата обращения: 15.03.2019).

[11] Сабитов Д. Информационная безопасность Казахстана: защита данных и смыслов / Институт мировой экономики и политики (ИМЭП) при Фонде Первого Президента Республики Казахстан - Лидера Нации. Астана - Алматы, 2016. URL: http://iwep.kz/files/attachments/article/2016-04-07/doklad_informacionnaya_bezopasnost_ daniyar_sabitov.pdf (дата обращения: 15.03.2018).

[12] Угрожают ли Казахстану российские СМИ? // Central Asia Monitor. 2014. URL: https://camonitor.kz/13908-ugrozhayut-li-kazahstanu-rossiyskie-smi-aivanov.html (дата обращения: 15.03.2019).

[13] Фридман Э., Шейфер Р. Новые исследования СМИ Центральной Азии // Центральная Азия и Кавказ. 2011. Т. 14. № 4. С. 143-162.

[14] Президент Казахстана расставил приоритеты: цифровизация и кибербезопасность на 8 месте. URL: https://digital.report/prezident-kazahstana-rasstavil-prioritetyi-tsifrovizatsiya-ikiberbezopasnost-na-8-meste/ (дата обращения: 20.06.2019).

[15] Бахтигареев P. Больше не многонациональный: обзор СМИ Казахстана // Regnum. 2017, 10 мая. URL: https://regnum.ru/news/2273031.html (дата обращения: 15.03.2019).

[16] Рашкоф $\phi$ Д. Медиавирус! Как поп-культура тайно воздействует на ваше сознание / пер. с англ. Д. Борисова. М.: Ультра.Культура, 2003. 368 с.

[17] Государственная программа развития и функционирования языков в РК. 2018. URL: https://strategy2050.kz/ru/page/gosprog5/ (дата обращения: 20.06.2019).

\section{История статьи:}

Дата поступления в редакцию: 31 января 2019

Дата принятия к печати: 10 октября 2019

\section{Для цитирования:}

Kinfu Z.T., Fadeeva A.A. Functional traits of the media space in Kazakhstan in the context of globalization (Особенности функционирования медиапространства Казахстана в условиях глобализации) // Вестник Российского университета дружбы народов. Серия: Литературоведение. Журналистика. 2020. Т. 25. № 1. С. 168-176. http://dx.doi.org/ 10.22363/2312-9220-2020-25-1-168-176

\section{Сведения об авторах:}

Кинфу Зенебе Тафессе, кандидат философских наук, доцент кафедры массовых коммуникаций филологического факультета, Российский университет дружбы народов. E-mail: zen888kin@yandex.ru

Фадеева Алина Александровна, аспирант кафедры массовых коммуникаций филологического факультета, Российский университет дружбы народов. E-mail: alina. fadeeva1092@gmail.com 